\title{
CLINICAL PROFILE AND SEXUAL BEHAVIORS IN PATIENTS OF SEXUALLY TRANSMITTED DISEASES IN A TEACHING HOSPITAL OF EASTERN NEPAL
}

\author{
Agrawal $\mathbf{S}^{1}$, Garg V K ${ }^{1}$, Agarwalla $\mathrm{A}^{1}$, Deb M ${ }^{2}$
}

\section{ABSTRACT}

A hospital based prospective cross sectional study was under taken over one-year period from April 1998 to March 1999 to study the clinical profile and sexual behavior in sexually transmitted diseases (STDs) patients at Dermatology and Venereology OPD at BPKIHS, Dharan, Nepal. A total of 105 patients giving history suggestive of STDs were studied. These patients were also enquired for their sexual behaviors. There were 85 males and 20 females; and the majority (55.2\%) was in the age group of 2130 years. Most of the patients $(\mathbf{2 5 . 7 \%})$ were students followed by housewives $(\mathbf{1 7 . 2 \%})$. service holders $(13.3 \%)$, businessmen $(13.3 \%)$, unemployed $(9.5 \%)$ and fanners $(8.5 \%)$.. Literates were $80 \%$. Sixty-eight percent males and $90 \%$ females were married. Majority of the males contracted infection from CSW $\mathbf{( 5 8 . 8 \% ) . ~ F e m a l e s ~ g o t ~ t h e ~}$ infection from husbands and friends. More than $50 \%$ of male had multiple partners whereas in case of females it was only $5 \%$. Homosexual and bisexual were $3.5 \%$ and 4.7\% respectively in males. Unprotected sexual contact was found in $94.1 \%$ of males and $100 \%$ of females. Syphilis $\mathbf{( 3 0 . 5 \% )}$ was the commonest type of STD followed by gonorrhea $(14.3 \%)$, genital warts $(14.3 \%)$, chancroid $(6.7 \%)$, candidiasis $(6.7 \%)$, herpes genitalis $(5.7 \%)$, mixed infection $(4.7 \%)$, donovanosis $(2.8 \%)$, and Lymphogranuloma venereum (0.9\%). In homosexual and bisexual, only NGU and syphilis were seen. STDs constituted $0.97 \%$ of all new dermatology patients. In spite of high proportion of promiscuous sexual behavior, there was only one HIV positive patient.

Key Words: Clinical profile, Sexual behavior, STD patients, Nepal.

1. Dept. of Dermatology and Venereology, B. P. Koirala Insitute of Health Sciences, Dharan, Nepal.

2. Dept. of Microbiology, B. P. Koirala Insitute of Health Sciences, Dharan, Nepal.

Address for correspondence : Dr. Sudha Agrawal, MD

Assistant Professor, Department of Dermatology and Venereology

B.P. Koirala Institute of Health Sciences, Dharan, Nepal.

Fax: 00977-25-20251, Email: sudha92@yahoo.com 


\section{INTRODUCTION}

Sexually transmitted diseases (STDs) reemerged as a major public health problem in most part of me world with the appearance of human immune deficiency virus (HIV) infection. STDs play an important role in transmission of HIV. The prevalence of STDs varies from country to country and even place to place within a country. ${ }^{1,2}$ It is an index of socio-economic status, moral out look, sexually active age group, and availability of treatment facilities and mass awareness of preventive measures in any community. ${ }^{3}$

Subedi in 1996 reported that up to $3 \%$ of the population was infected by some or other STD in Nepal. He suggested that there are pockets of high STD prevalence in some areas of Nepal because of tourism, girl trafficking, seasonal migration in search of temporary Job, low level of awareness on STD and AIDS \& unsafe sex practice. ${ }^{1}$ Very few STD prevalence data are available in Nepal and the most of the studies are confined to Kathmandu or me tourist spots in western part of the country. ${ }^{2,4}$ To the best of our knowledge, no data has been published on STD from the eastern Nepal. Therefore, the present study was conducted to know the clinical profile and sexual behavior in STD patients attending Dermatology and Venereology OPD of BPKIHS that is located in the eastern Nepal.

\section{MATERIAL AND METHODS}

A hospital based prospective cross sectional study was conducted in Dermatology and Venereology OPD of BPKIHS from April 1998 to March 1999. All me patients giving history suggestive of STDs were included. The detailed demographic data and clinical finding including history, general physical examination systemic and genital examination were recorded in a structured proforma.
VDRL and ELISA for HTV infection were done in all the patients. Gram's stain, Giemsa stain and crushed tissue smears were performed in me patients with genital ulcer diseases. Gram's stain and gonococcal culture were done in patients with urethral discharge for the diagnosis of gonococcal infection. If discharge was scanty, a urethral smear was made after asking the patient to hold the urine overnight. The patient was diagnosed as nongonococcal urethritis when urethral smear on Gram's stain showed pus cells more than 5 (in male)- 10 (in female) / HPF in the absence of other bacteria and with the signs of urethritis.

In female with vaginal discharge, high vaginal swabs were taken for demonstration of Trichomonas vaginalis, fungal elements and clue cells. Cervical smear was taken for N. gonorrheoae. Routine urine analysis, culture of urine and blood analysis was done whenever it was felt necessary. Dark ground illumination (DGI) could not be performed as this facility was not available. Each patient was enquired about his / her marital status, contraception practices, number and types of partners, different sexual practice and use of condom for sexual behavior.

\section{RESULTS}

STDs constituted $0.97 \%$ of all new Dermatology and Venereology out patients (10782) seen during the study period. Males constituted $85(81 \%)$ patients while females were $20(19 \%)$. Majority (55.2\%) belonged to the age group 21-30 years with age ranging from 4-50 years (mean $+\mathrm{SD}==26.0$ +6.32 years). Only $2.8 \%$ of cases were below 15 years of age. Most of the patients $(25.7 \%)$ were students followed by housewives (17.2\%), service holders (13.3\%), businessmen (13.3\%), unemployed $(9.5 \%)$, farmers $(8.5 \%)$ and others (12.3\%). Literate were $80 \%$, of which $35.7 \%$ had education up to primary level, $38.1 \%$ up to high 
school level and $26.2 \%$ up to secondary school and above level. Majority belonged to Koshi zone (74\%) followed by Sagarmatha (18\%), Mechi (6\%) and others $(2 \%)$. Sexual behavior of the patients is shown in Table 1 . The percentage of married males

Table 1 : Distribution of the Patients by their Sexual Behavior

\begin{tabular}{|c|c|c|c|}
\hline S. No. & Sexual Behavior & Male (85) & Female (20) \\
\hline \multirow[t]{4}{*}{1} & Marital Status & & \\
\hline & $\overline{\text { Married }}$ & $58(68.23)$ & $18(90.0)$ \\
\hline & Unmarried & $25(29.42)$ & $2(10.0)$ \\
\hline & Divorce & $2(2.35)$ & $0(0)$ \\
\hline \multirow[t]{4}{*}{2} & No. of Partners & & \\
\hline & $\overline{\text { Single }}$ & $34(40.0)$ & $19(95.0)$ \\
\hline & Multiple & $49(57.7)$ & $1(5.0)$ \\
\hline & Denied & $2(2.3)$ & $0(0)$ \\
\hline \multirow[t]{5}{*}{3} & Type of Sexual activity & & \\
\hline & $\overline{\text { Heterosexual }}$ & $76(89.5)$ & $19(100)$ \\
\hline & Homosexual & $3(3.5)$ & $0(0)$ \\
\hline & Bisexual & $4(4.7)$ & $0(0)$ \\
\hline & Denied & $2(2.3)$ & $0(0)$ \\
\hline \multirow[t]{6}{*}{4} & Source of infection & & \\
\hline & $\overline{\mathrm{CSW}}$ & $50(58.8)$ & $0(0)$ \\
\hline & Friends & 27 (31.9) & $2(10.0)$ \\
\hline & Relatives & $6(7.0)$ & $0(0)$ \\
\hline & Spouse & $0(0)$ & $18(90.0)$ \\
\hline & Denied & $2(2.3)$ & $0(0)$ \\
\hline \multirow[t]{5}{*}{5} & Sexual Practice & & \\
\hline & $\overline{\text { Genital }}$ & $76(89.5)$ & $24(100)$ \\
\hline & Anal & $3(3.5)$ & $0(0)$ \\
\hline & Genital + Anal & $4(4.7)$ & $0(0)$ \\
\hline & Denied & $2(2.3)$ & $0(0)$ \\
\hline \multirow[t]{5}{*}{6} & Use of condom & & \\
\hline & $\overline{\text { Regular }}$ & $3(3.6)$ & $0(0)$ \\
\hline & Occasional & 0 & $0(0)$ \\
\hline & Never & $80(94.1)$ & $20(100)$ \\
\hline & Denied & $2(2.3)$ & $0(0)$ \\
\hline
\end{tabular}

and females was 68.23 and 90.0 respectively. We recorded multiple partners in more than $50 \%$ of males, but in case of females it was only $5 \%$. In majority of males $(58.8 \%)$ the source of infection was commercial sex workers followed by friends (31.9\%). Homosexual and bisexual were $3.5 \%$ and $4.7 \%$ respectively in males. In case of females, $90 \%$ acquired infection from their husbands, who had histories of STDs in the past or at the time of presentation and rest $10 \%$ got infection from friends. All female patients (100\%) were heterosexuals. Unprotected sexual contact was found in $94 \%$ of males and $100 \%$ of females. Frequency of different STDs in the study population is depicted in table 2. Syphilis was the commonest

Table 2

Distribution and Frequency of STDs (Sexually Transmitted Diseases) in the Study Population

\begin{tabular}{|c|c|c|c|}
\hline Diseases & $\begin{array}{c}\text { Male } \\
\text { No. }(\%)\end{array}$ & $\begin{array}{l}\text { Female } \\
\text { No. }(\%)\end{array}$ & $\begin{array}{c}\text { Total } \\
\text { No. }(\%)\end{array}$ \\
\hline Syphilis & $26(30.6)$ & $6(30.0)$ & $32(30.5)$ \\
\hline Primary & $1(3.8)$ & $0(0.0)$ & $1(3.2)$ \\
\hline Secondary & $19(73.0)$ & $4(66.7)$ & $23(71.8)$ \\
\hline Latent & $6(23.2)$ & $2(33.3)$ & $8(25.0)$ \\
\hline Genital warts & $7(8.2)$ & $8(40.0)$ & $15(14.3)$ \\
\hline Gonorrhoea & $11(13.0)$ & $4(20.0)$ & $15(14.3)$ \\
\hline Non-gonococcal urethritis & $14(16.5)$ & $0(0.0)$ & $14(13.4)$ \\
\hline Chancroid & $7(8.2)$ & $0(0.0)$ & $7(6.7)$ \\
\hline $\begin{array}{l}\text { Candidiasis } \\
\text { Candidal Balanoposthitis/ } \\
\text { Vulvovaginitis }\end{array}$ & $5(5.9)$ & $2(10.0)$ & $7(6.7)$ \\
\hline Herpes genitalis & $6(7.0)$ & $0(0.0)$ & $6(5.7)$ \\
\hline Mixed infection & $5(5.9)$ & $0(0.0)$ & $5(4.7)$ \\
\hline Donovanosis & $3(3.5)$ & $0(0.0)$ & $3(2.8)$ \\
\hline $\begin{array}{l}\text { Lymphogranuloma } \\
\text { venereum }\end{array}$ & $1(1.2)$ & $0(0.0)$ & $1(0.9)$ \\
\hline Total & $85(100.0)$ & $20(100.0)$ & $105(100.0)$ \\
\hline
\end{tabular}

STD $(30.5 \%)$ followed by gonorrhoea $(14.3 \%)$ and genital warts $(14.3 \%)$, non-gonococcal urethritis (13.4\%), chancroid (6.7\%), herpes genitalis $(5.7 \%)$ and mixed infection (4.7\%). Candidiasis was observed in $5.9 \%$ of males presenting as balanoposthitis and $10 \%$ of females as vulvovaginitis. Donovanosis constituted $2.8 \%$ of all STDs. Lymphogranuloma venereum (LGV) was only $0.9 \%$. Mixed infection observed as gonorrhoea with genital warts, gonorrhoea with syphilis (each of 2 cases) and candidiasis with syphilis (1 cases). Among the patients having syphilis, the percentage of primary syphilis, secondary syphilis and latent syphilis were 3.2, 71.8 and 25 respectively. Nongonococcal urethritis and syphilis were the diseases in homosexual and bisexual. HIV serology positivity was found in only $0.72 \%$ of cases. 


\section{DISCUSSION}

STDs constituted $0.97 \%$ of all new Dermatology and Venereology patients in our study while up to $3 \%$ STDs was reported in a population based study from Nepal. ${ }^{1}$ In this study, males were more than the females as also observed by others from India. This may be because of fear of social stigma and lack of typical clinical lesions in female. ${ }^{2,3,5}$ In our study, the youngest patient was 4 years boy. His mother denied any history of sexual abuse in the boy. It might be he acquired infection by direct contact with his mother who had condyloma lata lesion. The majority of the patients belonged to the age group of 21-30 years because there is maximum sexual activity in this age group. ${ }^{6}$ The number of STD patients below 15 years of age was only $2.8 \%$ in me study like other reports. ${ }^{7,8}$ The occupation of the study group was a wide mixture similar to the reports in literature. ${ }^{4,9}$ Literate out numbered the illiterate and majority of the patients had education up to high school level, which is in agreement with other study. ${ }^{4}$ Married predominated unmarried similar to other studies. ${ }^{4,10}$ Homosexual and bisexual were very few and were only males. ${ }^{11,12}$ It may be because this type of sexual habits is not common in developing countries like Nepal. Commercial sexual workers were the commonest source of infections. This is in agreement with the findings of other studies. ${ }^{6,13}$ The females blamed their husbands as a source of infection as also reported by Mohanty, Das and Mishra. ${ }^{13}$ The high degree of promiscuous sexual behavior among males might be responsible for their multiple partners and numbers. ${ }^{9,13}$ Unprotected sexual exposures in our patients may be ignorance, a different culture and individual variations. ${ }^{14,15}$ Syphilis was the commonest STDs in the present study similar to other Indian studies, ${ }^{16,17}$ however Subedi et al from Nepal reported gonorrhoea as the commonest STDs followed by syphilis. ${ }^{8}$ Only one case of primary syphilis was seen in the present study. It may be the patients with genital ulcers prefer to receive treatment by private practitioners and avoid attending the hospitals. More cases of latent and secondary syphilis suggests that either the patients are not seeking treatment in time or are inadequately treated.

The prevalence of herpes genitalis has been reported more in many studies ${ }^{16,17}$ than in our study, where it constituted only $5.7 \%$. Donovanosis formed $2.8 \%$ of all sexually transmitted diseases. It is similar to others observation in India ${ }^{19}$ but no case of this disease has previously been reported from Nepal. Donovanosis occurs more in countries with a warm and humid climate. The eastern region of Nepal has a tropical monsoon climate with high humidity and temperature ranging from $9.9^{\circ} \mathrm{C}$ to $35.3^{\circ} \mathrm{C}$. Because of this climate, donovanosis might be found in our study. Chancroid and LGV were very uncommon in our study and is comparable with other study. ${ }^{13}$ Genital warts constituted $14.3 \%$ which is much higher than those reported from others. ${ }^{13,20}$ It might be there is an increasing trends towards viral STDs. ${ }^{11}$ Balanoposthitis was almost equal to that reported by Reddy et. al. ${ }^{21}$ Nongonococcal urethritis was higher in the present study than other study. ${ }^{20}$ It was also common in homosexual patients, which is in agreement with other report. ${ }^{10}$ Although, trichomoniasis and bacterial vaginosis are common STDs in females. no case of it was seen in the present study because the majority of females prefer to attend the gynaecology OPD for discharge per vagina. HTV serology positivity was low $(0.7 \%)$ and was almost equal to that reported from Kathmandu and Nepalgung. ${ }^{2,3}$

\section{CONCLUSION}

Syphilis appears to be the commonest STDs in eastern Nepal followed by gonorrhoea, genital warts and non- gonococcal urethritis. LGV and 
donovanosis seem to be rare in this part of Nepal. In spite of varied sexual behavior, HTV serology positivity was low; it is always better to screen all STD attendees for HTV antibody. The patients should be educated by community members through mass media and interpersonal strategies to reduce the risk behavior because behavior change is the key of STD prevention. As the incidence of the various STDs varies from place to place and from time to time a comprehensive national survey is advisable to identify the pattern of STDs all over the country, which will help to formulate and implement national STD control program well.

\section{REFERENCES}

1. Suredi BK. Sexually transmitted diseases in Nepal. J Nep Med Assoc 1996; 34: 277-278.

2. Bhargava NC, Sing OP, Lal N. Analytical study of 1000 cases of venereal disease. mo J Dermatol Venereol Leprol 1975; 41: 70-73.

3. Ranganayakulu B, Ravi Kumar GP, Bhaskar GV, Reddy N Sreenivasula. Pattern of sexually transmitted diseases at Kurnool. Ind J Sex Trans Dis 1998; 19: 117-121

4. Kapaun Aimette, Bista KP. Specific STD in symptomatic patient attending DV and Gynae OPD. SID/ HIV project. Ministry of Health, Department of Health Services. National centre for AIDS and SID control, University offleidillberg. 1998.

5. Mehta Swami D, Jaswal R, Bed RK, Kanwar AJ. Pattern of sexually transmitted diseases in New Northern Indian Hospital. Ind J Sex Trans Dis 1998; 19: 109-111.

6. Grean M Moore. The homosexual in the VD clinic. Br J Vener Dis 1964; 40:135-140.

7. Ginzburg HM, Fleming PL, Miller KD. Selected public health observation derived from the multicentric AIDS control study. J AIDS 1988; 1(1); 2-7.

8. Girish KG. Pattem of sexually transmitted diseases in Allahabad. Ind J Sex Iran Dis 1990; 1:6-8.
9. Grover Vijay, Kannan AT, Indrayan A, Sharma SC. Sexually transmitted diseases awareness and sexual behaviour: a study in clinical setting in urban areas of Delhi. hid J Sex Trans Dis 1999; 20 (I) : 16-20.

10. Ganguti DD, Sundharam JA, Bhagava NC. A study of behavioural aspects of sexually transmitted diseases, hid J Dermatol venereol Leprol 1983; 49:11-16.

11. Bansal NK, Khara AK, Upadhyay OP. Pattern of STDs in and around Udaipur. Indian J Dermatol venereol Leprol 1988; 54: 90-92

12. Bhargava NC, Tewari VK. STD patients: A profile, hid J Sex Trans Dis 1988; 9: 68-70.

13. Mohanty J, Das KB, Mishra C. Clinical profile of STDs in Cuttack. hid J Dermatol Veneral Leprol 1995; 61: 143-4.

14. P. Jeyasingh, Venkataratnav R, IBBSV Ramanajah. Study of use of condom by men attending STD clinic, hid J Sex Trans Dis 1986; 7: 27-29.

15. Ross MW. Attitude towards condoms and condom use: a review, hit J of SID and AIDS 1992; 3:1016.

16. Becker $\mathbb{T M}$, Blount JH, Guinan ME. Genital herpes infection in private practice in the United State: 1966-1981. JAMA 1985; 253 (II) : 1601-1603.

17. Siddappa K, Jagannath Kumar V, Ravindra K. Pattern of STDs at Davangere. hid J Sex Trans Dis 1990; 11: 39-42.

18. Kumar B, Raja Gopalan M. Rising incidence of genital herpes in a STD clinic in North India. GenUrinMed; 1989, 67:353-54.

20. Lal S, Nicholas C. Epidemiological and clinical features in 165 cases of granuloma inguinale. $\mathrm{Br}$ Jvener Dis 1970 ; 46: 461-463.

21. Vora NS, Dave JN, Mukhopadhyay AK. A profile of sexually transmitted diseases at Apex Esis Hospital Ahmedabad. hid J Sex Trans Dis 1994; 15: 36-38.

22. Reddy BSN, Garg BR, Rao MV. An appraisal of trends in SIDs. hid J Sex Trans Dis 1993; 14: 1-4. 